\title{
The Problem and Solution about the China art Design Theory Education
}

\author{
Chang Yan \\ College of Art, Xi'An University of Science and Technology,58 Yanta Road, Xi'an 710054, Shaanxi Province, \\ China \\ g_ychang@163.com
}

\begin{abstract}
This article analyzes the problems of college art design theory education with its development in recent years. Probes into the necessity for students majoring on art design to study art design theory, and puts forward some advices on how to improve art design theory education. Including the concept of change, to improve the status of art and design theory in teachers and students, to strengthen the building of teacher, teaching method improvement and change the existing entrance examination enrollment mode, ensure the artistic kind of examinee admitted to university has the basic conditions of professional courses and culture class quality.
\end{abstract}

KEYWORD: Art; Design Theory; Education

\section{FOREWORD}

In the art design works exhibition recent years, it is easily found many design works whose author desire to express a kind of idea eight it's advanced or alternative. But they are always feeled missing something that is not expression patten, but the actual connotation. Even if it's the purely idea design, it should have deeply meaning. So why this kind of works are produced more and more nowerdays? There are two possible reasons: One is the author copy the existing design patten, never import its own innovation or thought. The other is the design process goes with the author's thinking Unconstrainedly without theory guidance. Eighther of them leads to less of innovation in the students disign works, and can not inspire deeply thinking to people.

There is a matual theroy architecture about the relationship between theroy and practice after deeply research and disucss by the ancient andmodern, Chinese and foreign scholars. "Theroy guide practice" is widely accecpted principle. But students hardly generate interesting to study theroy becaue of arid in their living and studying, especially for the students who majored in art design which requires more specialisation. they love painting and design, unwittingly pay more attention to the specialized courses, but ignor the cultural courses such as University Chinese, English, advanced mathematics, even if the special theroy courses. This will lead to the student lack of guidance from theroy and their works having no deeply thinking. So it is very import to improve the teaching on theroy courses. How to enhance the art design theroy education and make students to study more actively? This artical maily discusses the problems in art design theroy education and try to find some solution to it.

\section{THE PROBLEMS IN ART DESIGN THEROY EDUCATION}

2.1 First of all, there are problem of he teaching object which can be Divided into two types of students: One is loving art and design who exposure to art, studying painting in their childhood. 'interesting leads them to study hard in the major courses'[1]. But they have no interesting in studing theroy. The other is with relative low college entrance examination result of cultrual courses, but they want to enter to relative good university. So they study hard on painting only before exams. With the advantage of relative high cultrual courses examination result compared with the first kind of education, they successfully enter an art university. This kind of students neight like art design, nor the design theroy study. This two Present situation proves there are problem in the teaching object.

2.2 Secondly, we are lack of art design theroy Teaching materials. Design Education in China in the true sense began in twentieth Century 80's. Guangzhou Acmdemy of Fine Arts toke the lead 
in its original arts and crafts department integration, and later expanded to the Department of Arts and craftsand Design Department in 1989. It was a short span of 20 years which is also the time of researching in the art theroy designing of our country. There are some achievement, but according the the publications, most of them still stay on the data sorting. If is necessary to study foreign publications if someone want to research on art theroy design which is a big difficulty to the researcher. The current design theory courses at various levels and of different types of institutions of higher education mainly includes the following types: The history of design, graphic design history, and design introductionetc. The famous design theorist Mr. Wang Shouzhi are living in American more than 20 years. His design of book which is an innovation to the domestic art design researching has become the Essential reference books for domestic postgraduate entrance examination. His books, although the data is very strong, but not suitable for beginner design theory of reading of College Students. The most needed for Students of China majored in design is an easy to start, the design theory of seriessystem, illustrated theory Series.

2.3 The last, China university teaching of major in design pays more attention to the theory, but ignore the practice. Many colleges and universities are anxious to cultivate master professional skills of the talents, emphasizing practice and light theory, utilitarian education thought is serious. In this case, they don't tend to hire specialized majors teachers of professional design theory to give students profession theoretical courses, but let the existing teacher that studies are now selling, course credits is basically the half the practicecourse. 'Ignore the importance of theoretical education, too much emphasis on skills training, this reflected in many of the school course offered' [2]. This has caused the vicious spiral that teaching quality can't get design theory to improve the effectiveness.

\section{DISCUSSION ON THE SOLUTION TO THE PROBLEM IN ART AND DESIGN THEORY OF EDUCATION}

3.1 First of all, change idea, improve the status of art and design theory in teachers and students. Colleges and universities should guide the students to the comprehensive development as soon as the student enroll in, pay attention to theory courses study, increase the theoretical courses in the curriculum and the proportion of the overall credit, which reflects the importance of design theory in the whole course system. For example, theory curriculum in the famous German Bauhaus School of design accounted for more than 30\%, including the design theory, design history, history of art and the modern design history, aesthetics and other related theory course[5]. Until now, some famous foreign design institutions still attach great importance to the cultivation of students with basic design theory which are worthy of our reference.

3.2 Secondly, strengthen the construction of teachers' team. Art design theory belongs to the marginal subject, requires teachers mastering solid theoretical foundation, also have the practical ability. Schools should try to provide good conditions for the teachers, make teachers have the opportunity to go abroad for further study or to participate in various domestic training; Teachers themselves should read widely all kinds of books, pay attention to cultivate and improve their own quality, make their discipline knowledge constantly updated to keep up with the pace of the world. 'From 2001, Tsinghua University Academy of Fine Arts offer to Grade 2000's undergraduates the Chinese and foreign history of design courses (grade two in autumn and spring respectively in each semester)' The Chinese design history course provide by MR. Hangjian is teached by the subject of books, utensils and room class topics; Foreign design history which is provided by teacher Zhang $\mathrm{Fu}$ is mainly about western modern design historysince the industrial revolution[4]. The famous design theorist professor Wang Shouzhi provide teaching design history curriculum each semester at Shantou University for undergraduate and postgraduate, many teachers in design theory are attracted to listen his courses. He also collaborated with the Jiangnan University into senior design theory class, providing a good platform for teachers to improve the level of theory. Teachers should take the initiative to listen to the course of top-level scholars at home and abroad, study teaching methods.

3.3 Thirdly, the improvement of teaching methods, let the students participate in the teachers' teaching activities. The design process of the previous theory teaching is the single teacher's lecture, one-way indoctrination and mechanical memory, never mention the enthusiasm of the students. The author thinks that should make full use of multimedia effects, timely, appropriately for students to watch design case effect, provide analysis and description targetedly. Play some video materials, guiding students' interest. In addition, arrange some interesting topic, let them gather information in their spare time, and launches the discussion in the classroom. These measures can promote the 
exchanges between teachers and students, improving teaching quality.

3.4 Finally, change the existing entrance exam mode, guarantee the basic conditions for artistic examinee who admitted to university have professional class and culture class education. Admission exam mode in most of the art colleges in China is the first to take the professional course test,after obtaining the corresponding scores, then attend the common university entrance exam, finally adding percentage of professional course and culture class scores together, then admit the best examinee. This model inevitably to give students to take advantage of the machinism.' It is suggested to take cultural courses over the line, with professional and culturaltotal and preferential admission way as a transition, and must be taken not to choose at random in the process of the implementation of the principle'[6]. The author thinks that it is desirable. On the basis, the professional course test content should also be carefully studied. For example, the examinee of professional fashion design should be added to the examinee test of dynamic sketch, the sketch modeling ability; Animation design candidates should pay attention to the students to study the characters modeling, abserve the expression ability. Only in this way, can explore the candidates suitable for the professional ability, also can avoid the rush for students majoring in art, to ensure students' cultural class level and professional quality.

\section{REFERENCES}

[1] Yu Shuying, Shi fan, "Analysis of students of art culture course and the professional course learning imbalance", Baoding Vocational \& Technical College, VOL.1, 2006.

[2] Zeng Xiaohong, "Preliminary study on Higher School of art and design theory of Education", Journal of Xiangtan Normal University (Social Science Edition), vol.7, 2006.

[3] Wang Shouzhi. "The world of modern design history", Chinese Youth Press, pp.34, 2002.

[4] Zhu shuai, "China mainland art design theory 20 years", Art Observation, vol.9, 2002.

[5] Zhang xiaowei, "Reflections on the reform of artistic design education Chinese" , Art Panorama, VOL.12, 2007. 